\title{
Effects of controlled environmental changes on the mineralization of soil organic matter
}

\author{
In-Young Choi, Hang Vo-Minh Nguyen, Jung Hyun Choi ${ }^{\dagger}$ \\ Department of Environmental Science and Engineering, Ewha Womans University, Seoul 03760, Republic of Korea
}

\begin{abstract}
This study investigated how the combined changes in environmental conditions and nitrogen $(\mathrm{N})$ deposition influence the mineralization processes and carbon (C) dynamics of wetland soil. For this objective, we conducted a growth chamber experiment to examine the effects of combined changes in environmental conditions and $\mathrm{N}$ deposition on the anaerobic decomposition of organic carbon and the emission of greenhouse gases from wetland soil. A chamber with elevated $\mathrm{CO}_{2}$ and temperature showed almost twice the reduction of total decomposition rate compared to the chamber with ambient atmospheric conditions. In addition, $\mathrm{CO}_{2}$ fluxes decreased during the incubation under the conditions of ambient $\mathrm{CO}_{2}$ and temperature. The decrease in anaerobic microbial metabolism resulted from the presence of vegetation, which influences the litter quality of soils. This can be supported by the increase in $\mathrm{C} / \mathrm{N}$ ratio over the experimental duration. Principle component analysis results demonstrated the opposite locations of loadings for the cases at the initial time and after three months of incubation, which indicates a reduction in the decomposition rate and an increasing $\mathrm{C} / \mathrm{N}$ ratio during the incubation. From the distribution between the decomposition rate and gas fluxes, we concluded that anaerobic decomposition rates do not have a significantly positive relationship with the fluxes of greenhouse gas emissions from the soil.
\end{abstract}

Keywords: Climatic change, Decomposition rate, Flux, N deposition, Soil organic matter

\section{Introduction}

Human activities such as the burning of fossil fuels and various land-use practices have increased the concentrations of greenhouse gases, such as carbon dioxide $\left(\mathrm{CO}_{2}\right)$, methane $\left(\mathrm{CH}_{4}\right)$, ozone, nitrous oxide, and chlorofluorocarbons. The $\mathrm{CO}_{2}$ concentration in the atmosphere has increased by approximately $35 \%$ since the industrial revolution and is predicted to reach $700 \mathrm{ppm}$ by the end of this century. Global warming caused by enhanced greenhouse effects has increased the worldwide air temperature by $1.4-5.8^{\circ} \mathrm{C}$ from the pre-industrial level [1].

Rising atmospheric $\mathrm{CO}_{2}$ concentration generally stimulates photosynthetic carbon (C) fixation by $30-70 \%$ [2]. As a consequence, plant biomass growth and $\mathrm{C}$ input into ecosystems have increased by an average of approximately $30 \%$ [3]. The productivity of vegetation growth enters the soils by plant leachates, root exudates, and plant litter [4], which is converted back to $\mathrm{CO}_{2}$ and $\mathrm{CH}_{4}$ through heterotrophic respiration processes [5, 6]. The balance between the input of $\mathrm{C}$ via photosynthesis and losses by respiration is a key aspect to determining whether a soil is a $\mathrm{C}$ source or sink
[6]. In water-saturated anoxic sediments, the organic $\mathrm{C}$ in soils can be mineralized by several interacting microbial processes [7-9]. In water-saturated anoxic wetland soils, the anaerobic decomposition of organic $\mathrm{C}$ regulates both the amount of organic material that is stored in soils and the amount of mineralized $\mathrm{C}$ that can be released into the atmosphere as greenhouse gases $\left(\mathrm{CO}_{2}\right.$ and $\mathrm{CH}_{4}$ ). Temperature is a major factor regulating decomposition rates. It has been observed that there are higher soil $\mathrm{CO}_{2}$ concentrations during the summer months than during the winter months [10, 11]. In addition, elevated atmospheric $\mathrm{CO}_{2}$ has increased organic $\mathrm{C}$ decomposition by either a priming effect from root exudates or aerobic decomposition from oxygen release (or radial oxygen loss) from roots [12]. However, results from nitrogen $(\mathrm{N})$ deposition experiments led to apparently contradictory hypotheses regarding the decomposition of organic $\mathrm{C}$ in soil. $\mathrm{N}$ deposition has been found to decrease the decomposition of chemically complex $\mathrm{C}$ compounds, while increasing the decomposition rates of labile $\mathrm{C}$ pools [13]. Combined changes in $\mathrm{N}$ deposition and environmental conditions have considerable potential to affect soil $\mathrm{C}$ sequestration/loss and soil nutrient cycling. $\mathrm{N}$ deposition and environmental
This is an Open Access article distributed under the terms of the Creative Commons Attribution Non-Commercial License (http://creativecommons.org/licenses/by-nc/3.0/) which permits unrestricted non-commercial use, distribution, and reproduction in any medium, provided the original work is properly cited.
Received January 5, 2017 Accepted April 4, 2017

${ }^{\dagger}$ Corresponding author

Email: jchoi@ewha.ac.kr

Tel: +82-2-3277-6686 Fax: +82-2-3277-3275

Copyright (C) 2017 Korean Society of Environmental Engineers 
conditions can each alter the activity of microbial decomposers, influencing the quantity of $\mathrm{C}$ lost (greenhouse gas emission or emission of greenhouse carbon gases) from soils via respiration, as well as the chemical quality of the $\mathrm{C}$ retained in soils as decomposition byproducts.

Soil, as the largest terrestrial $\mathrm{C}$ pool, stores almost three times as much $\mathrm{C}$ as terrestrial biomass [14]. In particular, wetlands store up to one-third of the total soil C pool, even though they occupy a relatively small percentage of the world's land area [15, 16]. Therefore, it is crucial to understand how wetland soil processes, and ultimately the changes in soil $\mathrm{C}$ dynamics, are affected by combined changes in environmental conditions and $\mathrm{N}$ deposition.

The objective of this study was to investigate how the combined changes in environmental conditions and $\mathrm{N}$ deposition affect the mineralization processes and C dynamics of wetland soil. Special focus was given to the extent of changes in the anaerobic decomposition of organic $\mathrm{C}$ and the emission of greenhouse gases. The results of this study are expected to elucidate the response of the mineralization of soil organic matter and the formation of greenhouse gases to various scenarios of climate change and cultivation practices.

\section{Materials and Methods}

\subsection{Study Site}

The wetland of interest is located below the confluence of the Kyoungan stream and the Han River in South Korea (Fig. 1). The study site is characterized by freshwater riparian wetlands and is bordered by an agricultural area. The water temperature of the adjacent river ranges from $2^{\circ} \mathrm{C}$ in February to $24-30^{\circ} \mathrm{C}$ from May to September (Korea Meteorological Administration, Korea). The total monthly rainfall ranges from $1.5 \mathrm{~mm} \cdot \mathrm{mon}^{-1}$ in February to $242.5 \mathrm{~mm} \cdot \mathrm{mon}^{-1}$ in August (Korea Hydro and Nuclear Power Company, Korea). The dominant aquatic plants at the study site are Phragmites australis and Zizania latifolia [17]. The surface of the sediments is typically saturated with water throughout the year. However, the weather conditions (i.e., low precipitation and high light intensity) during the summer allow the surface of the sediments to be exposed to air occasionally.

\subsection{Experimental Setup}

In June 2011, we collected soil samples from a depth of $10 \mathrm{~cm}$, homogenized them, and added them to each of eight polyvinyl chloride (PVC) pots $(25 \mathrm{~cm}$ diameter $\times 33 \mathrm{~cm}$ height). Pots were sealed on the bottom with a PVC cap and had 1-cm-diameter holes covered with screens at $5 \mathrm{~cm}$ above the base to allow for water exchange (or sampling). Of the eight pots, four were planted with Zizania latifolia (planted-treatment) and four were left unplanted (unplanted-treatment). Each planted-treatment pot received eight separate plants corresponding to a pre-determined typical field density. Galloway et al. [18] estimated that South and East Asia would receive $\mathrm{N}$ deposition of $5,000 \mathrm{mg} \mathrm{N} \cdot \mathrm{m}^{-2} \cdot \mathrm{y}^{-1}$ from the atmosphere by 2050. To investigate the effects of $\mathrm{N}$ deposition, we added $\mathrm{N}$ to half of the planted and unplanted pots. The amount of nitrogen added, $0.02 \mathrm{~g} \mathrm{NH}_{4} \mathrm{NO}_{3}$ per month, was calculated using the ratio

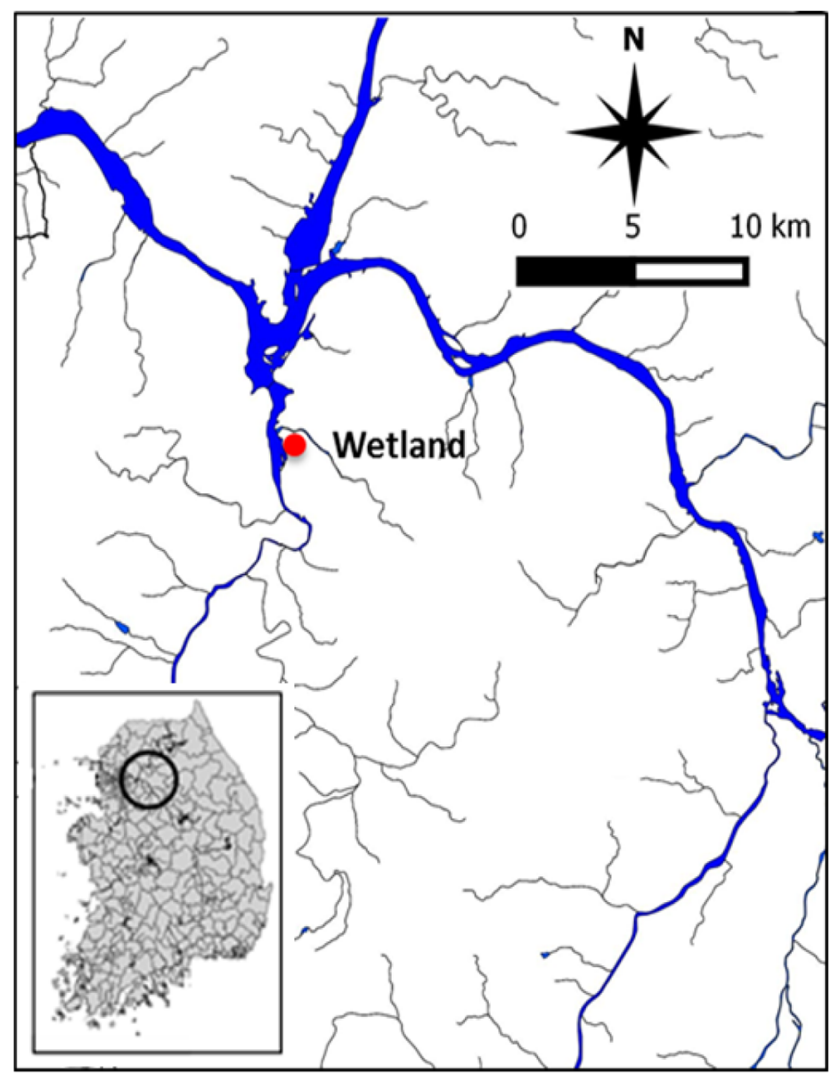

Fig. 1. Map of the study site.

between the surface area of Asia and the surface area of an experimental pot, $490 \mathrm{~cm}^{2}$ (= $\left.12.5 \mathrm{~cm} \times 12.5 \mathrm{~cm} \times 3.14\right)$.

A laboratory experiment was carried out using environmentally controlled plant growth chambers. The growth chambers were $1.4 \mathrm{~m}$ wide $\times 0.74 \mathrm{~m}$ deep $\times 1.2 \mathrm{~m}$ high and were equipped with a blower for drawing ambient air through the chamber, allowing for control of the $\mathrm{CO}_{2}$ concentration and air temperature. One chamber was maintained at an ambient atmospheric $\mathrm{CO}_{2}$ concentration of approximately $390 \mathrm{ppm}$ and temperatures of $18^{\circ} \mathrm{C}$ during the night and $23^{\circ} \mathrm{C}$ during the day. Based on the A1B scenario of the Intergovernmental Panel on Climate Change AR4 report, the $\mathrm{CO}_{2}$ concentration is predicted to reach over $720 \mathrm{ppm}$ by the end of this century [19]. To simulate the altered environmental conditions caused by climatic change, the second chamber was maintained at an elevated $\mathrm{CO}_{2}$ concentration of approximately $720 \mathrm{ppm}$ and a temperature of $22^{\circ} \mathrm{C}$ at night and $27^{\circ} \mathrm{C}$ during the day. The $\mathrm{CO}_{2}$ concentration in each chamber was monitored continuously using a Binos gas analyzer (KORINS KRG701, Korea). The average day length was approximately 14 hours during this experiment.

Each chamber contained four pots (two unplanted pots and two planted pots). $\mathrm{N}$ was added to two of these pots (one unplanted pot and one planted pot). Depending on the presence of controlling factors, such as vegetation and nitrogen, there were four different conditions in each growth chamber (Table 1). Cases I and II represent the conditions of the growth chamber, while numbers (1-4) represent 
Table 1. Experimental Setup Used in This Study

\begin{tabular}{|c|c|c|c|c|}
\hline \multirow{2}{*}{ Sample } & \multirow{2}{*}{ Name } & \multicolumn{3}{|c|}{ Controlling Factors } \\
\hline & & $\mathrm{CO}_{2} \&$ Temp. & Vegetation & Nitrogen \\
\hline \multirow{4}{*}{ Case I } & 1 & $\mathrm{X}$ & $\mathrm{X}$ & $\mathrm{X}$ \\
\hline & 2 & $\mathrm{X}$ & $\mathrm{O}$ & $\mathrm{X}$ \\
\hline & 3 & $\mathrm{X}$ & $\mathrm{X}$ & $\mathrm{O}$ \\
\hline & 4 & $\mathrm{X}$ & $\mathrm{O}$ & $\mathrm{O}$ \\
\hline \multirow{4}{*}{ Case II } & 1 & $\mathrm{O}$ & $\mathrm{X}$ & $\mathrm{X}$ \\
\hline & 2 & $\mathrm{O}$ & $\mathrm{O}$ & $\mathrm{X}$ \\
\hline & 3 & $\mathrm{O}$ & $\mathrm{X}$ & $\mathrm{O}$ \\
\hline & 4 & $\mathrm{O}$ & $\mathrm{O}$ & $\mathrm{O}$ \\
\hline
\end{tabular}

$\mathrm{X}$ : absence of controlling factors, O: presence of controlling factors

the values of the controlling factors. For example, Case I- 1 is a case without vegetation, with $\mathrm{N}$, ambient $\mathrm{CO}_{2}$, and temperature. Case II-4 is with vegetation, with nitrogen, elevated $\mathrm{CO}_{2}$ concen tration, and temperature. Pots were assigned to the chambers randomly. Each pot was filled to the soil surface with water from the river adjacent to the riparian wetlands where the soil was sampled. The previously published paper by Choi et al. (2013) provided more detailed information of the experimental design and chamber conditions [20].

\subsection{Sample Collection and Laboratory Analyses}

The anaerobic decomposition of organic $\mathrm{C}$ is regulated by the supplies of both electron acceptors and electron donors and by the competition between microbial groups for these resources [21]. The outcome of microbial competition depends on the energetic efficiency of individual metabolic pathways and therefore depends on sequential patterns of microbial activity of $\mathrm{NO}_{3}^{-}$reduction, $\mathrm{Fe}$ (III) reduction, $\mathrm{SO}_{4}{ }^{2-}$ reduction, and methanogenesis. Since organic $\mathrm{C}$ is converted into $\mathrm{CO}_{2}$ and $\mathrm{CH}_{4}$ through the anaerobic decomposition processes, the rate of anaerobic $\mathrm{C}$ decomposition can be determined as the sum of $\mathrm{CO}_{2}$ and $\mathrm{CH}_{4}$ production over time. In August (beginning of the experiment) and November (end of the experiment), we collected replicate soil cores ( $\geq 10 \mathrm{~cm} \mathrm{depth)} \mathrm{in} \mathrm{the}$ pots of growth chambers using PVC tubes (10-15 cm diameter). The cores were capped on the bottom to minimize $\mathrm{O}_{2}$ leakage into the soil and were transported to the lab. Each core was transferred to a $\mathrm{N}_{2}$-filled glove bag, and samples were collected for biogeochemical rate measurements. For the measurement of anaerobic decomposition rates, we measured the rates of $\mathrm{CO}_{2}$ and $\mathrm{CH}_{4}$ production from the soil slurries. Soil slurries were prepared in serum bottles using $5 \mathrm{~mL}$ soil and $5 \mathrm{~mL}$ oxygen-free deionized water. The production of $\mathrm{CO}_{2}$ and $\mathrm{CH}_{4}$ was measured in sealed serum bottles over periods of 3-10 days. At each of several time points, $500 \mu \mathrm{L}$ of headspace gas was collected for $\mathrm{CO}_{2}$ and $\mathrm{CH}_{4}$ analyses on a gas chromatograph (Agilent Technologies 7890A). Hyperbolic and linear regression analyses were used to calculate $\mathrm{CO}_{2}$ and $\mathrm{CH}_{4}$ production rates; for the hyperbolic curves, the initial part of the curve was used. Soil mass-normalized rates were converted to $\mathrm{C}$ units using a 2:1 molar ratio of mineralized $\mathrm{C}$ per $\mathrm{CH}_{4}$ produced based on the results of [22] (1:1 molar ratio of $\mathrm{CO}_{2}: \mathrm{CH}_{4}$ production).

$\mathrm{CO}_{2}$ and $\mathrm{CH}_{4}$ fluxes from individual pots were measured monthly between August and November 2011. A PVC flux chamber consists of a PVC pipe (10 cm height $\times 3 \mathrm{~cm}$ diameter $)$ with a PVC cap at one end. All PVC joints were sealed with silicone. The headspace was sampled through a rubber septum located on the cap of the flux chamber. During $\mathrm{CO}_{2}$ and $\mathrm{CH}_{4}$ efflux measurements, the bottom of the flux chamber was placed below the water surface, ensuring minimal gas exchange with the atmosphere. Samples for $\mathrm{CO}_{2}$ and $\mathrm{CH}_{4}$ analysis were collected once per hour over a 4 hour period. $\mathrm{CO}_{2}$ and $\mathrm{CH}_{4}$ were analyzed on a gas chromatograph (Agilent Technologies 7890A). Fluxes of $\mathrm{CO}_{2}$ and $\mathrm{CH}_{4}$ were calculated with the following equation [23]:

$$
F=(V / A) \cdot(d C / d t)
$$

where $F$ is gas emission $\left(\mu \mathrm{g} \cdot \mathrm{m}^{-2} \cdot \mathrm{h}^{-1}\right), V$ is chamber volume $\left(\mathrm{m}^{3}\right)$, $A$ is the soil surface area $\left(\mathrm{m}^{2}\right)$, and $d C / d t$ is the change in gas concentration in the chamber with time $\left(\mu \mathrm{g} \cdot \mathrm{m}^{-2} \cdot \mathrm{h}^{-1}\right)$.

To determine the dominant compounds in the soil used in this study, the amounts of $\mathrm{C}$ and $\mathrm{N}$ in the soil were measured. The air-dried wetland soil samples were sent to the National Instrumentation Center for Environmental Management (http://nicem.snu.ac.kr) for elemental analysis of $\mathrm{C}$ and $\mathrm{N}$.

\subsection{Statistical Analyses}

Differences in the anaerobic decomposition processes and water content of soils according to the environmental conditions were assessed using paired t-tests. Statistical significance was set at $p \leq 0.05$. Analyses were conducted using SPSS 20.0 (IBM SPSS Statistics). Principle component analysis (PCA) involves a mathematical procedure that transforms a number of correlated variables into a smaller number of uncorrelated (independent) variables based on the eigenvector decomposition of the covariance or correlation matrix. PCA was performed using XLSTAT (Addinsoft, New York, NY, USA). The significance of the correlations in the statistics was evaluated using $p$-values.

\section{Results}

\subsection{Anaerobic Decomposition Rate}

The anaerobic decomposition rates ranged from 2.55 to $4.17 \mathrm{mmol}$ $\mathrm{C} \cdot \mathrm{g}^{-1} \cdot \mathrm{d}^{-1}$ (dry mass basis) at the beginning of the experiment (August) and from 0.99 to $3.09 \mathrm{mmol} \mathrm{C} \cdot \mathrm{g}^{-1} \cdot \mathrm{d}^{-1}$ (dry mass basis) at the end of incubation (November) (Fig. 2). Since the anaerobic decomposition rates were consistently higher in the soils under the initial conditions of the experiment than in the soils after three months of incubation, there were significant decreases in the decomposition rates according to the incubation time. This was also observed by the comparison of anaerobic decomposition rates between the initial conditions and after three months of incubation using a paired t-test ( $p=0.001$ ). In August, pot 1 (no vegetation + no $\mathrm{N}$ addition) and pot 4 (vegetation $+\mathrm{N}$ addition) of Case I (with ambient $\mathrm{CO}_{2}$ concentration and temperature) showed higher decomposition rates, which implies that the combined effects of vegetation 
Table 2. Changes in $\mathrm{CO}_{2}$ and $\mathrm{CH}_{4}$ Fluxes According to Experimental Setup during the Incubation Period

\begin{tabular}{|c|c|c|c|c|c|c|c|}
\hline \multicolumn{2}{|c|}{$\mathrm{CO}_{2}$ Flux } & $\begin{array}{c}\text { Initial } \\
\left(\mu \mathrm{g} \cdot \mathbf{m}^{-2} \cdot \mathbf{h}^{-1}\right)\end{array}$ & $\begin{array}{c}\text { After } 3 \text { mon } \\
\left(\mu \mathrm{g} \cdot \mathrm{m}^{-2} \cdot \mathrm{h}^{-1}\right)\end{array}$ & \multicolumn{2}{|c|}{$\mathrm{CH}_{4}$ Flux } & $\begin{array}{c}\text { Initial } \\
\left(\mu \mathrm{g} \cdot \mathrm{m}^{-2} \cdot \mathbf{h}^{-1}\right)\end{array}$ & $\begin{array}{c}\text { After } 3 \text { mon } \\
\left(\mu g \cdot m^{-2} \cdot h^{-1}\right)\end{array}$ \\
\hline \multirow{4}{*}{ Case I } & 1 & 360.00 & 247.27 & \multirow{4}{*}{ Case I } & 1 & 0.89 & 1.78 \\
\hline & 2 & 354.55 & 283.12 & & 2 & -3.26 & 0.00 \\
\hline & 3 & 799.10 & 214.81 & & 3 & -0.30 & 0.00 \\
\hline & 4 & 193.64 & 267.27 & & 4 & -19.72 & 2.22 \\
\hline \multirow{4}{*}{ Case II } & 1 & 957.27 & 93.64 & \multirow{4}{*}{ Case II } & 1 & 57.00 & 0.00 \\
\hline & 2 & 101.82 & 154.77 & & 2 & 141.48 & 4.00 \\
\hline & 3 & 447.00 & 631.71 & & 3 & 0.30 & 40.28 \\
\hline & 4 & 848.18 & 507.66 & & 4 & 103.89 & 4.88 \\
\hline
\end{tabular}

${ }^{*}$ Some of the data shown in this table are from a previously published paper, Choi et al. (2013).
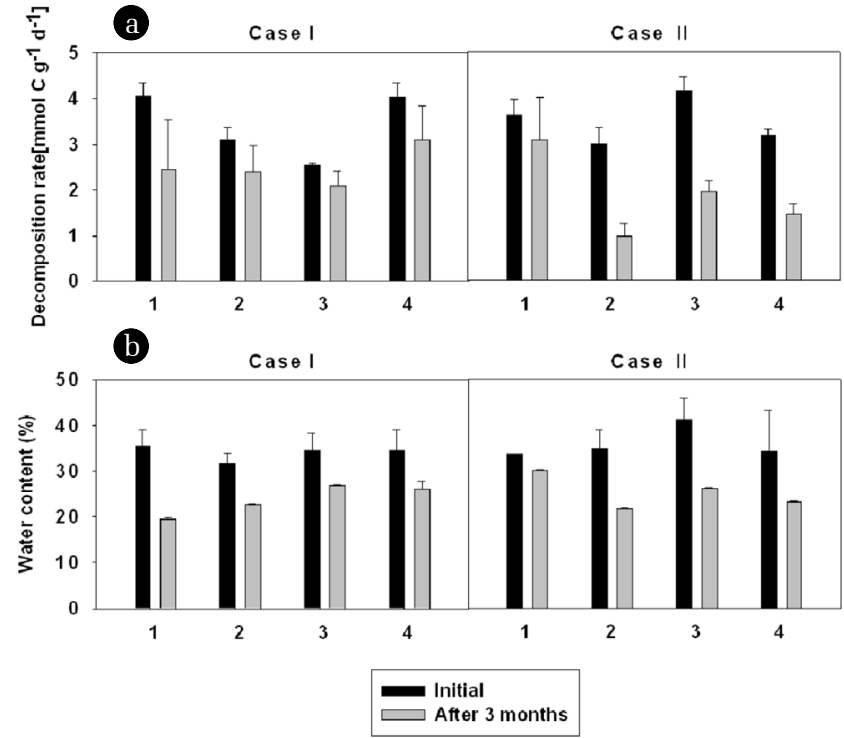

Fig. 2. Changes in organic matter decomposition rates and moisture content according to experimental setup during the incubation period: (a) Decomposition rate $\left(\mathrm{mmol} \mathrm{C} \cdot \mathrm{g}^{-1} \cdot \mathrm{d}^{-1}\right)$ and (b) water content (\%). The bars represent the standard errors.

and $\mathrm{N}$ addition had an impact on the anaerobic microbial metabolism in the soils. In Case II (with elevated $\mathrm{CO}_{2}$ concentration and temperature), however, pot 1 (no vegetation + no $\mathrm{N}$ addition) and pot 3 (no vegetation $+\mathrm{N}$ addition) showed higher decomposition rates, which indicates that $\mathrm{N}$ addition was more important to the anaerobic microbial metabolism in the soils under changed environmental conditions. Considering the decreasing ratio of decomposition rates, the ratio of Case II (mean: 47.31\%) appears almost double that of Case I (mean: 25.64\%). The largest decrease in decomposition rate $(67.11 \%)$ was observed in Case II-2. The decreasing ratios of anaerobic microbial metabolism were consistently higher in pots II- 2 and II- 4 than in pots II- 1 and II-3, which implies that conditions of elevated $\mathrm{CO}_{2}$ concentration and temperature could decrease the anaerobic decomposition of organic matter in soils. In addition, the presence of vegetation stimulated a decrease in the total decomposition rate.

\subsection{Flux Measurements}

In the chamber with ambient $\mathrm{CO}_{2}$ and temperature (Case I), the $\mathrm{CO}_{2}$ fluxes were 360.0, 354.55, 799.10, and $193.64 \mu \mathrm{g} \mathrm{CO} \cdot \mathrm{m}^{-2} \cdot \mathrm{h}^{-1}$ for pots I-1, I-2, I-3, and I-4, respectively, in August (Table 2). There were decreases in the $\mathrm{CO}_{2}$ fluxes in November compared with those in August, except in Case I-4 (vegetation $+\mathrm{N}$ addition). In the chamber with elevated $\mathrm{CO}_{2}$ and temperature (Case II), $\mathrm{CO}_{2}$ fluxes varied from 101.82 to $957.27 \mu \mathrm{g} \mathrm{CO}_{2} \cdot \mathrm{m}^{-2} \cdot \mathrm{h}^{-1}$ in August. Compared to the stabilized $\mathrm{CO}_{2}$ fluxes of the chamber with ambient $\mathrm{CO}_{2}$ and temperature (Case I), the $\mathrm{CO}_{2}$ fluxes for pots II- 1 (no vegetation + no $\mathrm{N}$ addition) and II-4 (vegetation $+\mathrm{N}$ addition) were larger than those of pots II-2 (vegetation + no $\mathrm{N}$ addition) and II-3 (no vegetation $+\mathrm{N}$ addition). There were no statistically significant changes in $\mathrm{CO}_{2}$ fluxes during the three months of incubation.

The $\mathrm{CH}_{4}$ flux was negligible from the pots in all treatments. In August, the $\mathrm{CH}_{4}$ fluxes were 0.89. -3.26, -0.30, and $-19.72 \mu \mathrm{g}$ $\mathrm{CH}_{4} \cdot \mathrm{m}^{-2} \cdot \mathrm{h}^{-1}$ for pots I-1, I-2, I-3, and I-4, respectively. There were increases in $\mathrm{CH}_{4}$ fluxes in all samples during the incubation with ambient $\mathrm{CO}_{2}$ and temperature (Case I). In Case I-4 (vegetation + $\mathrm{N}$ addition), the $\mathrm{CH}_{4}$ flux was increased by $21.94 \mu \mathrm{g} \mathrm{CH}_{4} \cdot \mathrm{m}^{-2} \cdot \mathrm{h}^{-1}$ during incubation. The $\mathrm{CH}_{4}$ fluxes did not show any differences among the treatments in November.

In the chamber with elevated $\mathrm{CO}_{2}$ and temperature (Case II), however, there were significant decreases of $\mathrm{CH}_{4}$ fluxes, except for Case II-3, during the incubation. The $\mathrm{CH}_{4}$ fluxes were decreased by more than $100 \mathrm{mg} \mathrm{CH} \mathrm{CH}_{4} \cdot \mathrm{m}^{-2} \cdot \mathrm{h}^{-1}$ for pots II-2 (vegetation + no $\mathrm{N}$ addition) and II-4 (vegetation $+\mathrm{N}$ addition).

From the growth chamber incubation experiment, we observed that elevated $\mathrm{CO}_{2}$ and temperature decreased $\mathrm{CH}_{4}$ fluxes, while there was an opposite trend in the chamber with ambient $\mathrm{CO}_{2}$ and temperature. In addition, the presence of vegetation intensified the decrease in $\mathrm{CH}_{4}$ fluxes, which might have resulted from the decomposition of organic matter in the soils. Initial measurements of both $\mathrm{CO}_{2}$ and $\mathrm{CH}_{4}$ fluxes were conducted 1-2 days after the initiation of the experiment. Since the soil was completely homogenized before setting up the experiment, we assumed that similar values of $\mathrm{CO}_{2}$ and $\mathrm{CH}_{4}$ fluxes would be observed at the beginning of the experiment. However, from the results of the flux measurements, we inferred that the short-term stabilization period of 1-2 days resulted in differences between the fluxes. 


\subsection{Soil $\mathrm{C}$ and $\mathrm{N}$ Pools}

Initial soil $\mathrm{C}$ and $\mathrm{N}$ concentrations were $1.7 \%$ and $0.2 \%$, respectively, and the $\mathrm{C} / \mathrm{N}$ ratio was 8.5. After three months of incubation, the $\mathrm{C}$ and $\mathrm{N}$ concentrations were significantly higher than the initial concentrations (Fig. 3). The average C concentrations were $2.18 \%$ and $2.29 \%$ in Cases I and II, respectively, at the end of the incubation. The increase in $\mathrm{C}$ concentration under elevated $\mathrm{CO}_{2}$ and temperature (Case II) was larger than the increase in $\mathrm{C}$ concentration under ambient conditions (Case I). The pots with $\mathrm{N}$ additions were generally more responsive to increases in $\mathrm{C}$ concentration in the soil at elevated $\mathrm{CO}_{2}$ and temperature in comparison with those under ambient conditions. The increase in $\mathrm{C}$ concentration at elevated $\mathrm{CO}_{2}$ and temperature was $61 \%$ higher in those pots with $\mathrm{N}$ deposition. The average $\mathrm{N}$ contents were $0.13 \%$ and $0.14 \%$ in Cases I and II, respectively, at the end of the incubation period. The increase in $\mathrm{N}$ concentration under elevated $\mathrm{CO}_{2}$ and temperature was slightly larger than the increase in $\mathrm{N}$ content under ambient conditions. Without a doubt, $\mathrm{N}$ addition was effective in increasing the $\mathrm{N}$ concentration in the soil. The increase in $\mathrm{N}$ concentration was more than doubled in the pots with $\mathrm{N}$ deposition at elevated $\mathrm{CO}_{2}$ and temperature.
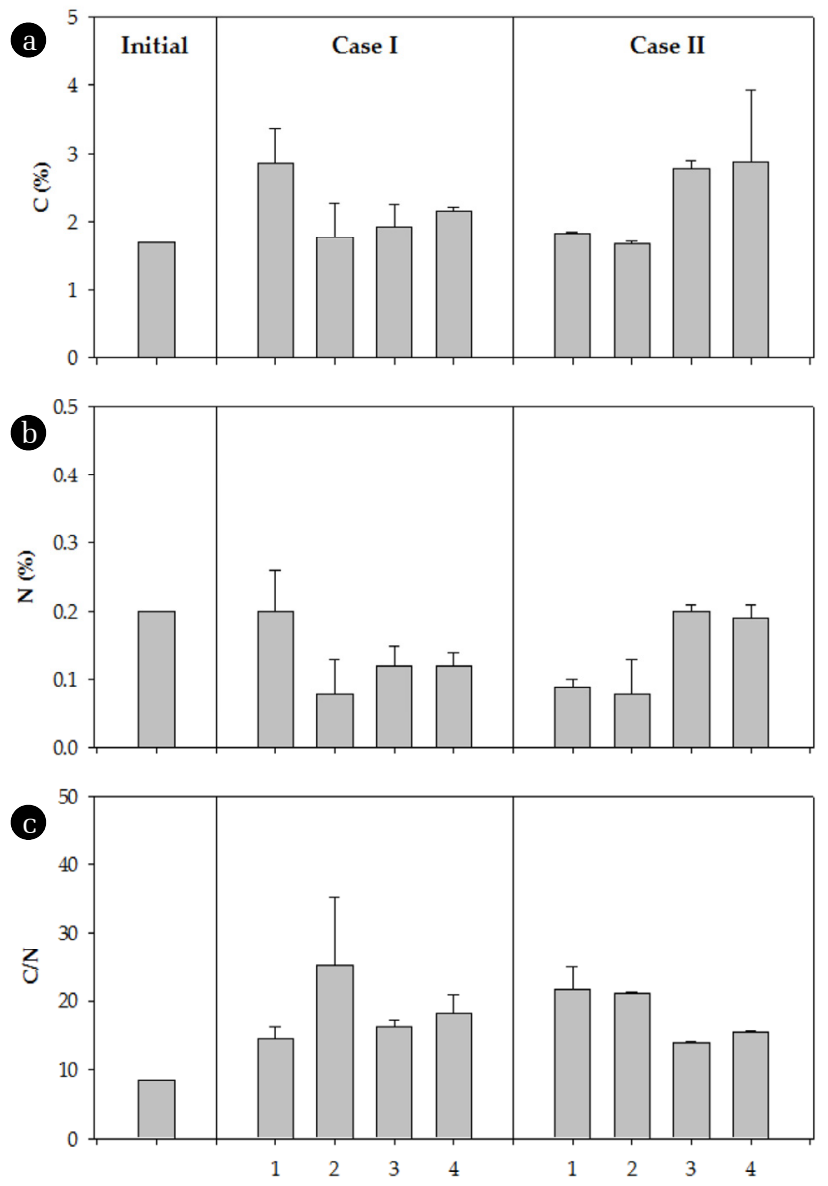

Fig. 3. Constituents of (a) $\mathrm{C}(\%)$ and (b) $\mathrm{N}(\%)$ and (c) the $\mathrm{C} / \mathrm{N}$ ratios of soils. Some of the data shown in this table are from a previously published paper, Choi et al. (2013).
The average $\mathrm{C} / \mathrm{N}$ ratio over the entire experimental duration more than doubled both under ambient conditions and with elevated $\mathrm{CO}_{2}$ and temperature. Both $\mathrm{C}$ and $\mathrm{N}$ concentrations were more responsive to the environmental conditions $\left(\mathrm{CO}_{2}\right.$ and temperature) and to $\mathrm{N}$ addition.

\subsection{Statistical Analyses}

A total of eight selected parameters were included in the PCA, namely, decomposition rate, water content, $\mathrm{CH}_{4}$ flux, $\mathrm{CO}_{2}$ flux, $\mathrm{CH}_{4}+\mathrm{CO}_{2}$ fluxes, \%C, \%N, and $\mathrm{C} / \mathrm{N}$. The first two principal components explained approximately $72.7 \%$ of the variance. Correlations between the first two components and the measured parameters were predicted in a loading plot (Fig. 4(a)). From the results, the first factor (PC1) explained approximately $49.05 \%$ of the variance. PC1 was negatively correlated with decomposition rate, water content, $\mathrm{CO}_{2}, \% \mathrm{~N}$, total $\mathrm{CO}_{2}$, and $\mathrm{CH}_{4}$, whereas the ratio of $\mathrm{C} / \mathrm{N}$ was positively correlated with PC1. The second factor (PC2) accounted for $23.65 \%$ of the total variance and is significantly related to \%C.
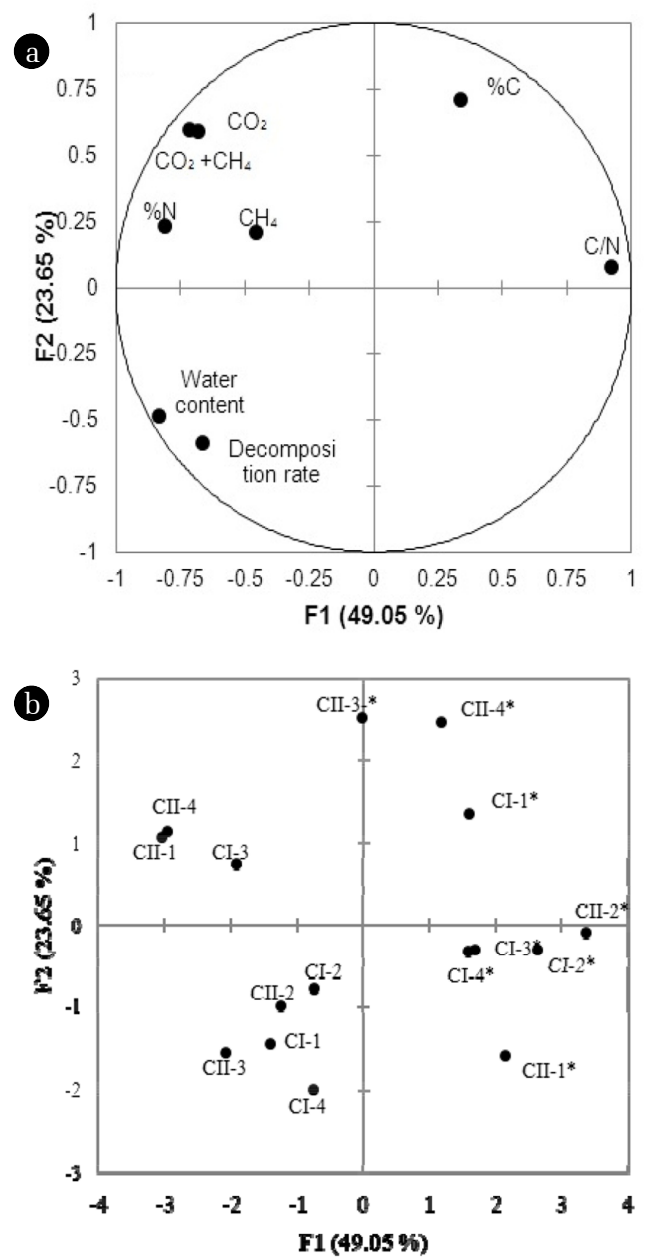

Fig. 4. Results of PCA analysis: (a) factor loading plot for the measured properties as the first two principal components; (b) factor scores plot for each sample as the first two principal components $(*$ : samples after three months of incubation). 
From the PCA results, PC1 is related to the decomposition rate, flux, and constituent of $\mathrm{N}$, while PC2 is related to the constituent of $\mathrm{C}$ in the soil. The locations of water content and decomposition rate in Fig. 2 showed a strongly positive correlation between these two parameters. The flux of $\mathrm{CO}_{2}$ and total flux of $\mathrm{CO}_{2}$ and $\mathrm{CH}_{4}$ presented a positive correlation with $\% \mathrm{~N}$ in the soil samples. However, the decomposition rates did not relate to the gas fluxes $\left(\mathrm{CH}_{4}, \mathrm{CO}_{2}\right.$, and $\left.\mathrm{CH}_{4}+\mathrm{CO}_{2}\right)$ according to location in the loading plot (Fig. 4(a)).

From the score plot (Fig. 4(b)), the distributions of the samples in November and those samples in August were in opposite locations in PC1 and PC2. After three months of incubation, the pots I-2*, $\mathrm{I}-3^{*}, \mathrm{I}-4^{*}, \mathrm{II}-1^{*}$, and II-2* (where * denotes the time point after three months of incubation) showed a negative relation with the decomposition rate and a positive correlation with the ratio of $\mathrm{C} / \mathrm{N}$. On the other hand, a different trend was reported for pots I-3, II-1, and II-4 in August. For PC2, pots II- $3^{*}$ and II- $4^{*}$ in November exhibited a positive relationship with $\% \mathrm{C}$, and a negative trend was observed for pots I-1, I-2, and I-4 in August. Pots II- 1 and II-4 were positively related with the flux of $\mathrm{CO}_{2}$, combined fluxes of $\mathrm{CO}_{2}$ and $\mathrm{CH}_{4}$, and $\% \mathrm{~N}$, while pots I-1 and I-4 were associated with the decomposition rate. The loadings of pots II- $3^{*}$ and II- 4 * were located close together and were positively related to the $\% \mathrm{C}$ in the soil, whereas pots I- $3^{*}$ and I- $4^{*}$ were closely related to the ratio of $\mathrm{C} / \mathrm{N}$. Pots $\mathrm{II}-1^{*}$ and $\mathrm{II}-2^{*}$ were identified as having similar characteristics of decomposition with low water contents and high ratios of $\mathrm{C} / \mathrm{N}$.

\section{Discussion}

Increased $\mathrm{C}$ input into the soil with elevated $\mathrm{CO}_{2}$ enhances the protection of organic matter in soil aggregates from microbial decomposition [24, 25]. The rate of decomposition from soil organic matter to dissolved organic carbon (DOC) and $\mathrm{CO}_{2}$ is dependent on a number of environmental factors, including temperature, moisture, plant residue composition, and the capacity of the soil to stabilize soil organic matter [26, 27]. Temperature is a major factor in the regulation of decomposition rates. It has been observed that there are higher soil $\mathrm{CO}_{2}$ concentrations during the summer compared with those of winter months $[4,10]$. However, the temperature sensitivity of soil organic matter decomposition remains a topic for debate [28].

In this study, we observed decreases in the decomposition rates during the incubation period. Considering the decreasing ratios of decomposition rates, the chamber with elevated $\mathrm{CO}_{2}$ concentration and temperature showed higher decreasing ratios compared to those of the chamber with ambient $\mathrm{CO}_{2}$ concentration and temperature. Among the Case II pots, the decreasing ratios of anaerobic microbial metabolism were consistently higher in the pots with vegetation than in the pots without vegetation, which implies that the presence of vegetation stimulates decreases in total decomposition rates by influencing the litter quality of the soils. In the wetland systems where this has been studied, the rate of microbial-mediated decomposition was dependent on substrate quality, $\mathrm{pH}$, and on oxygen and nutrient availability, the combination of which tends to stabilize soil organic matter [29]. Under anaerobic conditions, decomposition processes tend to produce DOC rather than the gaseous forms of $\mathrm{C}$ and $\mathrm{N}$ as primary end products [7]. Since decomposition rates vary considerably, however, the accessibility of organic matter to the microbial community is an essential factor in determining the $\mathrm{C}$ balance of the soil system.

Two factors are considered to predict the accessibility of organic matter, which controls decomposition rates; first, the chemical and structural aspects of organic matter are responsible for differences in decay rates; second, the chemical ratio, as defined by a simple index that summarizes important chemical aspects of organic matter, is a controlling factor. In many studies, $\mathrm{N}$ content and, more usually, the $\mathrm{C} / \mathrm{N}$ ratio, are used as predictors of decomposition rates [30-33]. Taylor et al. (1989) showed that there were consistent negative correlations between decay rates and $\mathrm{C} / \mathrm{N}$ ratios. It has been considered that the $\mathrm{C} / \mathrm{N}$ ratio merely describes the proportions of $\mathrm{C}$ to $\mathrm{N}$, without indicating any additional chemical characteristics of the organic matter. However, organic matter that is high in $\mathrm{C}$ tends to be low in nutrients ( $\mathrm{N}$ and phosphorus (P)) and high in lignin. Thus, for many uncontaminated and natural systems, it appears that the $\mathrm{C} / \mathrm{N}$ ratio actually contains significant information relating to the general chemical composition [34]. In addition, Berg and coworkers [35-37] have independently developed a more refined model of the influence of organic matter quality on decomposition. They demonstrated that $\mathrm{N}$ and other nutrients such as $\mathrm{P}$ and sulfur (S) control decay rates during the first phases of decay, while lignin content becomes progressively more important thereafter.

We observed that the average $\mathrm{C} / \mathrm{N}$ ratio over the entire experimental duration more than doubled both under ambient conditions and under elevated $\mathrm{CO}_{2}$ and temperature conditions. The increased $\mathrm{C} / \mathrm{N}$ ratio explains the large increase in carbon and relatively small increase in $\mathrm{N}$ throughout the three months of incubation. The increased $\mathrm{C}$ concentrations are more responsive to the changes in environmental conditions $\left(\mathrm{CO}_{2}\right.$ and temperature) as well as to $\mathrm{N}$ additions. Rising atmospheric $\mathrm{CO}_{2}$ concentration generally stimulates photosynthetic C fixation by $30-70 \%$ [2]. As a consequence, plant biomass growth and $\mathrm{C}$ input into ecosystems increased by an average

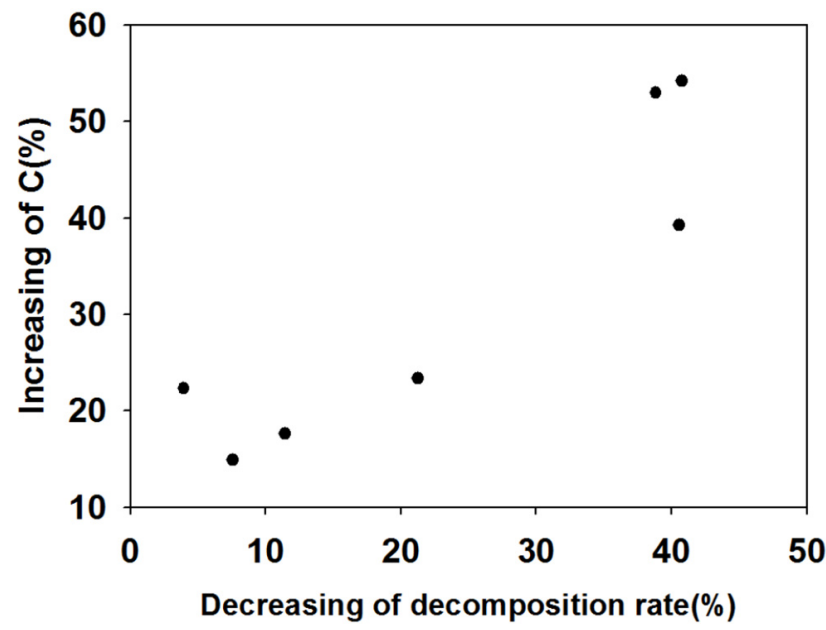

Fig. 5. Pattern of increasing ratio of $\mathrm{C}(\%)$ and decreasing ratio of decomposition rate (\%). 
of approximately 30\% [3]. From Fig. 5, between the increasing ratio of $\mathrm{C}$ values and the decreasing ratio of decomposition rates, we concluded that a decrease in decomposition rates resulted in an increase in $\mathrm{C} / \mathrm{N}$ ratio by changing the $\mathrm{C}$ input in this experiment.

Emissions of greenhouse gases $\left(\mathrm{CO}_{2}\right.$ and $\left.\mathrm{CH}_{4}\right)$ from wetland soil did not show any consistent trend in accordance with the changes in decomposition rate. However, $\mathrm{CO}_{2}$ fluxes under the ambient $\mathrm{CO}_{2}$ and temperature and $\mathrm{CH}_{4}$ fluxes under the elevated $\mathrm{CO}_{2}$ and temperature showed decreasing trends corresponding to the decomposition rate during incubation. In addition, the presence of vegetation intensified the decrease in $\mathrm{CH}_{4}$ fluxes, which might have resulted from the decomposition of organic matter in the soils.

Ecosystems have a number of processes that can lead to net $\mathrm{N}$ accumulation under conditions of elevated $\mathrm{CO}_{2}$. Those processes include biological $\mathrm{N}$ fixation, retention of atmospheric $\mathrm{N}$ deposition, reduced $\mathrm{N}$ loss in gaseous and liquid form, and extended root growth to the root-free zone for $\mathrm{N}$ uptake [38]. Heterotrophic decomposition is likely to be sensitive to $\mathrm{N}$ deposition, both because microbial decomposers are sensitive to changes in the $\mathrm{C} / \mathrm{N}$ ratios of organic material and because of potential shifts in the microbial community composition with added N. N deposition has also been found to decrease the decomposition of poorer quality litter and to suppress respiration during the later stages of decomposition.

We found that $\mathrm{N}$ addition slowed soil $\mathrm{C}$ losses by decreasing the heterotrophic decomposition under elevated $\mathrm{CO}_{2}$ and temperature. The N-fertilized soils (pots II-3 and II-4) had 61\% higher soil $\mathrm{C}$ concentrations than soils without $\mathrm{N}$ additions (pots II-1 and II-2). Reductions in heterotrophic decomposition have also been observed in temperate ecosystems with $\mathrm{N}$ additions $[39,40]$ and in a temperate grassland with high $\mathrm{N}$ inputs [41]. Our results showed a similar trend for two samples (II-3 and II-4) under elevated $\mathrm{CO}_{2}$ and temperature, with $\mathrm{N}$ addition slowing the turnover of the $\mathrm{C}$ pool. Since the soil $\mathrm{C}$ concentration of Case II-4 (vegetation $+\mathrm{N}$ addition) was slightly larger than that of Case II-3 (no vegetation $+\mathrm{N}$ addition) and their difference was less than $9 \%$ of the soil $\mathrm{C}$ concentration of Case II-4, there was little $\mathrm{C}$ input from the presence of vegetation under the conditions of elevated $\mathrm{CO}_{2}$ and temperature. It seems that the slower $\mathrm{C}$ loss due to $\mathrm{N}$ addition was the primary reason for the increased bulk soil $\mathrm{C}$ concentrations.

The composition of organic matter appears to play a central role in how heterotrophic decomposition responds to $\mathrm{N}$ deposition across ecosystems [42]. The quality of organic matter in this study was poor, with high $\mathrm{C} / \mathrm{N}$ ratios, especially in Case II-4, where the greatest increases in soil $\mathrm{C}$ were observed. In addition, $\mathrm{N}$ addition corresponded to increased temperature sensitivity of heterotrophic decomposition in both samples (vegetated and non-vegetated pots), with the greatest effect being observed for Case II-4 (vegetation $+\mathrm{N}$ addition).

Finally, the PCA results presented the opposite locations of loadings for the cases in August and November, which indicates a decrease in the decomposition rate and an increase in the $\mathrm{C} / \mathrm{N}$ ratio during the incubation period of three months. In addition, the distributions of the decomposition rates and gas fluxes $\left(\mathrm{CH}_{4}\right.$, $\mathrm{CO}_{2}$, and $\mathrm{CH}_{4}+\mathrm{CO}_{2}$ ) indicated that there was no consistent trend in gas flux changes during the incubation. Based on these results, we concluded that anaerobic decomposition rate was not significantly positively correlated with fluxes of greenhouse gas $\left(\mathrm{CO}_{2}\right.$ and $\mathrm{CH}_{4}$ ) emissions from the soil.

From the score plot (Fig. 4(b)), the distributions of loading plots for the samples after three months were separated into two main groups. The first group consisted of treatments that exhibited elevated $\mathrm{CO}_{2}$ concentration and temperature with the $\mathrm{N}$ addition condition (i.e., pots II- $3^{*}$ and II- $4^{*}$ ). This group was related to the $\% \mathrm{C}, \% \mathrm{~N}$, and the flux of $\mathrm{CO}_{2}$, which indicates a higher rate of decomposition even with the increases in $\mathrm{C}$ and $\mathrm{N}$ constituents. The second group was treatments under the ambient $\mathrm{CO}_{2}$ conditions (with and without $\mathrm{N}$ addition) and under elevated $\mathrm{CO}_{2}$ concentration without $\mathrm{N}$ addition (i.e., pots I-2*, I-3*, I-4*, II- ${ }^{*}$, and II-2*). These samples were positively associated with the ratio of $\mathrm{C} / \mathrm{N}$, indicating a lower microbial decomposition rate. Thus, factors that could strongly affect the microbial decomposition were the combination of $\mathrm{CO}_{2}$ and temperature increase and $\mathrm{N}$ addition.

\section{Conclusions}

This study investigated how the combined changes in environmental conditions and $\mathrm{N}$ deposition influenced the mineralization processes and $\mathrm{C}$ dynamics of wetland soil. For this objective, we conducted a growth chamber experiment to examine the effects of combined changes in environmental conditions and $\mathrm{N}$ deposition on the anaerobic decomposition of organic carbon and the emissions of greenhouse gases from wetland soil.

There were substantial decreases in total decomposition rates during the incubation period. The chamber with elevated $\mathrm{CO}_{2}$ and temperature showed almost twice the reduction in decomposition rates compared to the chamber with ambient environmental conditions. The decreasing ratios of anaerobic microbial metabolism were consistently higher in pots with vegetation than in pots without vegetation, which implies that the presence of vegetation stimulates decreases in total decomposition rates by influencing the litter quality of the soils. This can be supported by the increases in $\mathrm{C} / \mathrm{N}$ ratios over the entire experimental duration. Emissions of greenhouse gases $\left(\mathrm{CO}_{2}\right.$ and $\left.\mathrm{CH}_{4}\right)$ did not show any consistent trend in accordance with the changes in decomposition rate. However, the presence of vegetation intensified the decreases in $\mathrm{CH}_{4}$ fluxes, which might have resulted from the decomposition of organic matter in the soils. Anaerobic decomposition was also sensitive to $\mathrm{N}$ deposition. Through the higher soil $\mathrm{C}$ concentration with $\mathrm{N}$ addition, we found that $\mathrm{N}$ fertilization slowed soil $\mathrm{C}$ losses by decreasing heterotrophic decomposition under elevated $\mathrm{CO}_{2}$ and temperature.

PCA results presented the opposite locations of loadings for the cases at the initial time point and after three months of incubation, which indicates the decrease in decomposition rates and an increasing $\mathrm{C} / \mathrm{N}$ ratio during the incubation period. In addition, the distribution between decomposition rates and gas fluxes $\left(\mathrm{CH}_{4}, \mathrm{CO}_{2}\right.$, and $\left.\mathrm{CH}_{4}+\mathrm{CO}_{2}\right)$ demonstrated that anaerobic decomposition rates do not have a significantly positive relationship with fluxes of greenhouse gas $\left(\mathrm{CO}_{2}\right.$ and $\left.\mathrm{CH}_{4}\right)$ emissions from soil. 


\section{Acknowledgments}

This work was supported by a National Research Foundation of Korea grant funded by the Korean government (No. 2013R1A1A1058884).

\section{References}

1. Houghton RA. Revised estimates of the annual net flux of carbon to the atmosphere from changes in land use and land management 1850-2000. Tellus. B. 2003;55:378-390.

2. Luo Y, Mooney HA. Stimulation of global photosynthetic carbon influx by an increase in atmospheric carbon dioxide concentration. In: George WK, Harold AM, eds. Carbon dioxide and terrestrial ecosystems. San Diego: Academic Press; 1996. p. 381-397.

3. Kimball BA, Mauney JR, Nakayama FS, Idso SB. Effects of increasing atmospheric $\mathrm{CO}_{2}$ on vegetation. Vegetatio 1993;104-105:65-75.

4. Jones JJB, Mulholland PJ. Carbon dioxide variation in a hardwood forest stream: An integrative measure of whole catchment soil respiration. Ecosystems 1998;1:183-196.

5. Choi J, Kang H, Park S. Comparison of enzyme activities in vegetated and nonvegetated sediments. J. Environ. Eng. 2009;135:299-305.

6. Choi JH, Park SS, Jaffé PR. The effect of emergent macrophytes on the dynamics of sulfur species and trace metals in wetland sediments. Environ. Pollut. 2006;140:286-293.

7. Freeman C, Fenner N, Ostle NJ, et al. Export of dissolved organic carbon from peatlands under elevated carbon dioxide levels. Nature 2004;430:195-198.

8. Wang S, Choi JH. Simulating fate and transport of chromium in saturated sediments. Appl. Math. Model. 2013;37:102-111.

9. Chon $\mathrm{K}$, Cho J. Abundance and expression of denitrifying genes (nar $G$, nirS, norB, and nosZ) in sediments of wastewater stabilizing constructed wetlands. Environ. Eng. Res. 2015;21:51-57.

10. Castelle AJ, Galloway JN. Carbon dioxide dynamics in acid forest soils in shenandoah national park, Virginia. Soil. Sci. Soc. Am. J. 1990;54:252-257.

11. Scott MJ, Jones MN, Woof C, Tipping E. Concentrations and fluxes of dissolved organic carbon in drainage water from an upland peat system. Environ. Int. 1998;24:537-546.

12. Wolf AA, Drake BG, Erickson JE, Megonigal JP. An oxygen-mediated positive feedback between elevated carbon dioxide and soil organic matter decomposition in a simulated anaerobic wetland. Glob. Change Biol. 2007;13:2036-2044.

13. Cusack DF, Torn MS, McDowell WH, Silver WL. The response of heterotrophic activity and carbon cycling to nitrogen additions and warming in two tropical soils. Glob. Change Biol. 2010;16:2555-2572.

14. Schimel DS. Terrestrial ecosystems and the carbon cycle. Glob. Change Biol. 1995;1:77-91.

15. Gorham E. Northern Peatlands: Role in the carbon cycle and probable responses to climatic warming. Ecol. Appl. 1991;1: 182-195.

16. Jenkinson DS, Andrew SPS, Lynch JM, Goss MJ, Tinker PB.
The turnover of organic carbon and nitrogen in soil [and Discussion]. Phil. Trans. R. Soc. B. 1990;329:361-368.

17. Cho K, Kim J. Distribution of aquatic macrophytes in the littoral zone of Lake Paldang, Korea. Korean J. Ecol. 1994;17:435-442.

18. Galloway JN, Dentener FJ, Capone DG, et al. Nitrogen cycles: Past, present, and future. Biogeochemistry 2004;70:153-226.

19. Intergovernmental Panel on Climatic Change (IPCC). Climate change 2007: The physical science basis. New York: Cambridge Univ. Press; 2007.

20. Choi IY, Kang MK, Choi JH. Change of organic matter decomposition rates and greenhouse gas emission of the soil of Gyeongan stream under different environmental conditions. Korean J. Ecol. Environ. 2014;46:75-85.

21. Hedin LO, Joseph CF, Ostrom NE, Kennedy BP, Brown MG, Robertson GP. Thermodynamic constraints on nitrogen transformations and other biogeochemical processes at soil-stream interfaces. Ecology 1998;79:684-703.

22. Roden E, Wetzel R. Organic carbon oxidation and suppression of methane production by microbial Fe(III) oxide reduction in vegetated and unvegetated freshwater wetland sediments. Limnol. Oceanogr. 1996;41:1733-1748.

23. Rolston DC. Methods of soil analysis: Part 1. Physical and mineralogical methods. 2nd ed. Madison, Wisconsin: American Society of Agronomy/Soil Science of America; 1986.

24. Rillig MC. Arbuscular mycorrhizae and terrestrial ecosystem processes. Ecol. Lett. 2004;7:740-754.

25. Zak DR, Pregitzer KS, Curtis PS, Holmes WE. Atmospheric $\mathrm{CO}_{2}$ and the composition and function of soil microbial communities. Ecol. Appl. 2000;10:47-59.

26. Blanco-Canqui H, Lal R. Mechanisms of carbon sequestration in soil aggregates. Crit. Rev. Plant. Sci. 2004;23:481-504.

27. Coleman K, Jenkinson DS. RothC - A model for the turnover of carbon in soil. In: Powlson DS, Smith P, Smith JU, eds. Evaluation of soil organic matter models using existing, long-term datasets. NATO. ASI. Ser I. 1996;38:237-246.

28. Davidson EA, Janssens IA. Temperature sensitivity of soil carbon decomposition and feedbacks to climate change. Nature 2006;440:165-173.

29. Hobbie EA, Weber NS, Trappe JM. Mycorrhizal vs saprotrophic status of fungi: The isotopic evidence. New Phytol. 2001;150: 601-610.

30. Anderson JM. The breakdown and decomposition of sweet chestnut (Castanea sativa mill.) and beech (Fagus sylvatica L.) leaf litter in two deciduous woodland soils: II. Changes in the carbon, hydrogen, nitrogen and polyphenol content. Oecologia 1973;12:275-288.

31. Bocock KL. Changes in the amounts of dry matter, nitrogen, carbon and energy in decomposing woodland leaf litter in relation to the activities of the soil fauna. J. Ecol. 1964;52:273-284.

32. Taylor BR, Parkinson D, Parsons WFJ. Nitrogen and lignin content as predictors of litter decay rates: A microcosm test. Ecology 1989;70:97-104.

33. Ahn J, Jho EH, Nam K. Effect of $\mathrm{C} / \mathrm{N}$ ratio on polyhydroxyalkanoates (PHA) accumulation by Cupriavidus necator and its implication on the use of rice straw hydrolysates. Environ. Eng. Res. 2015;20:246-253.

34. Cromack K, Monk C. Litter production, decomposition, and 
nutrient cycling in a mixed hardwood watershed and a white pine watershed. In: Howell FG, Gentry JB, Smith MH, eds. Mineral cycling in southeastern ecosystems. ERDA sym- posium series (CONF-740513); 1975. p. 609-624.

35. Berg B. Decomposition of root litter and some factors regulating the process: Long-term root litter decomposition in a scots pine forest. Soil. Biol. Biochem. 1984;16:609-617.

36. Berg B. Nutrient release from litter and humus in coniferous forest soils - A mini review. Scand. J. Forest. Res. 1986;1:359-369.

37. Berg B, Agren GI. Decomposition of needle litter and its organic chemical omponents: Theory and field experiments. Long-term decomposition in a Scots pine forest. III. Can. J. Botany 1984;62:2880-2888.

38. Luo Y, Su BO, Currie WS, et al. Progressive nitrogen limitation of ecosystem responses to rising atmospheric carbon dioxide. BioScience 2004;54:731-739.

39. Burton AJ, Pregitzer KS, Crawford JN, Zogg GP, Zak DR. Simulated chronic $\mathrm{NO}_{3-}$ deposition reduces soil respiration in northern hardwood forests. Glob. Change Biol. 2004;10:1080-1091.

40. Olsson P, Linder S, Giesler R, Högberg P. Fertilization of boreal forest reduces both autotrophic and heterotrophic soil respiration. Glob. Change Biol. 2005;11:1745-1753.

41. Loiseau P, Soussana JF. Elevated $\left[\mathrm{CO}_{2}\right]$, temperature increase and $\mathrm{N}$ supply effects on the turnover of below-ground carbon in a temperate grassland ecosystem. Plant. Soil 1999;210:233-247.

42. Knorr W, Prentice IC, House JI, Holland EA. Long-term sensitivity of soil carbon turnover to warming. Nature 2005;433:298-301. 